Investigations

\title{
The Influence of Biorganic Fertilizers on Productivity and Quality of Vegetables in the System of "Green" Vegetable Farming in the Conditions of the South-East of Kazakhstan
}

\author{
Temirzhan Erkasovich Aitbayev, Zharas Zholdybaevich Mamyrbekov, \\ Akbope Temirzhanovna Aitbayeva, Bekzat Abievich Turegeldiyev and Birzhan Sultanuly Rakhymzhanov
}

Kazakh Research Institute of Potato and Vegetable Growing, 040917,

Nauryz Street 1, Kainar Town, Karasai District, Almaty Region, Republic of Kazakhstan

\author{
Article history \\ Received: $30-08-2017$ \\ Revised: $18-11-2017$ \\ Accepted: 29-01-2018 \\ Corresponding Author: \\ Temirzhan Erkasovich \\ Aitbayev \\ Kazakh Research Institute of \\ Potato and Vegetable Growing, \\ 040917, Nauryz Street 1, \\ Kainar Town, Karasai District, \\ Almaty Region, Republic of \\ Kazakhstan \\ Email: aitbayev-temirzhan@yandex.ru
}

\begin{abstract}
The purpose of the research was to study an influence of biofertilizers and new types of biological products for the yield and quality of vegetables in the South-East of Kazakhstan. In Kazakhstan, organic farming began to develop after the adoption of the Act "On Organic farming" in 2015. The development of "green" technologies is very important for the production of organic vegetable products in the country. The goal is the scientific provision of organic vegetable farming in Kazakhstan. Methods of research are classical, generally accepted in vegetable growing, agrichemistry and soil science. The studies on "green" agritechnologies in the vegetable farming of Kazakhstan are conducted for the first time, which determines their relevance and scientific novelty. The aim of the research was to study an influence of local organic fertilizers and new types of biofertilizers while growing the most popular vegetable crops (cabbage, cucumber, tomato) and replace chemical fertilizers by them in the condition of the South-East of Kazakhstan. Also, development of an alternative biological system for the fertilization of vegetable crops by using local organic fertilizers and biopreparations. It was experimented that all types of organic fertilizers and biopreparations ensure a sufficiently large yield of vegetables. It is noted that some organic fertilizers are more effective than mineral fertilizers. The bioorganic fertilizers positively influenced the quality of vegetables, so that the content of dry substances, sugars and vitamins increased in the production. The conclusion was made on the possibility of using local organic fertilizers and new biopreparations available to farmers of the country for growing organic vegetables. Depending on the types of organic fertilizers and biopreparations, the yield of cabbage increased by $15.2-47.2 \%$, cucumber by $17.4-88.7 \%$ and tomato by $14.4-47.1 \%$. Moreover, an improvement of the quality indicators of vegetables also showed in the crops.
\end{abstract}

Keywords: "Green" Vegetable Farming, Vegetable Crops, Organic Fertilizers, Biopreparations, Mineral Nutrition, Productivity, Quality

\section{Introduction}

Special attention and huge financial resources are paid for the organic agriculture throughout the world. The world agriculture is purposefully moving towards to the organic farming. In the leading countries of Europe, the USA, Canada and Australia legal, managerial and technological systems of farming and marketing of organic products are operating and constantly improving (Lotter, 2003; Bruulsema, 2003; Kirchmann et al., 2007; Gosling and
Shepherd, 2005; Paull and Lyons, 2008; Boyhan et al., 2009; Willer and Lernoud, 2016a; Willer et al., 2013; OFG, 2017; Willer and Lernoud, 2015; Ferreira et al., 2015; Willer and Lernoud 2016b; Paull and Hennig, 2016).

According to the International Federation of Organic Agriculture Movements (IFOAM) and the Research institute of Organic Agriculture (FiBL), the area of land under organic farming is continuously growing in the world. Since 2000 , the size has increased almost 3.5 times and amounted to 37.5 million hectares by 2012 
(164 countries). In Europe, all countries without exception have an organic sector. In Africa, the organic

Almost 1.9 million organic producers have been certified in the world, more than $3 / 4$ of which are in the developing countries. In the countries of the European Union, organic farming employs $5.6 \%$ of all agricultural land.

Moreover, organic agriculture in North America is 3.0 million hectares; Latin America - 6.8; Europe - 11.2; Asia - 3,2; Africa 1.1; Australia and Oceania - 12.2.

Organic food and farming markets operate in many countries of the world, primarily in the USA and the EU, where an appropriate infrastructure for the certification and sale of organic products has been established and is successfully operating (The results of the research, conducted by IFOAM (2014); The results of the research, 2014; The results of the research, conducted by FiBL and IFOAM, 2014; Stolze et al., 2012).

The motivation to consume organic products is environmental safety, high quality, freshness, best taste, preservation of the natural environment during farming and absence of genetically modified organisms (Pomigalov, 2004; Kharitonov, 2011; Khodakovskaya, 2011; Ganush, 2013; Grigoruk and Klimov, 2016; Sirota and Nadezhkin, 2008; Borisov, 2008; Malkov et al., 2006).

The organic vegetable farming is a production system that allows avoiding or substantially excluding the use of chemical fertilizers, pesticides and growth regulators provides for the preservation of the ecological balance and minimizing the negative impact on the environment (Dubovitsky and Klimentova, 2014).

In Kazakhstan, the production and market for ecologically safety products are at an early stage of development. The organic products in Kazakhstan are imported mainly from Europe, which entails high prices. At the same time, there are all opportunities for the development of the national organic farming. Moreover, many laws and other activities have been introduced to support further development of the organic agriculture in Kazakhstan. For instance, the political prerequisites and formal institutions for organic farming have been created. The Strategy "Kazakhstan-2050" was adopted, according to which Kazakhstan should become a global player in the market of ecologically safe products. Furthermore, the Act "On organic farming" (2015) introduced the rules for keeping the register of organic producers, the rules for farming and organic products and the list of allowed methods in the farming of organic products.

Potato, vegetable and melon farming are important branches of agriculture in Kazakhstan. According to the Kazakh Academy of Nutrition, the rate of potato consumption per capita is $100 \mathrm{~kg}$, vegetables - $120 \mathrm{~kg}$, melons - $26 \mathrm{~kg}$ (Sharmanov and Aidzhanov, 2000)

The soil and climatic conditions of Kazakhstan allow growing large volumes of potatoes, vegetables and melons, thus fully meeting the domestic market's demand. The farming is developing in $67 \%$ of countries, in Asia $76 \%$, in Latin America - $62 \%$. country has a large export potential for these types of products. According to the statistics, in 2016 in Kazakhstan, vegetable crops were cultivated in the area of 146.2 thousand hectares and 3.564 million tonnes of vegetables were harvested; potato was cultivated in 186.9 thousand hectares and harvest was 3.464 million tons; melon crops in 93.6 thousand hectares and harvesting amounted to 2.088 million tons. The potato security in Kazakhstan is $165 \%$, vegetables - $210 \%$, melons - 472\% (OSDASRK, 2017).

Vegetables are consumed fresh and after little processing. Therefore, environmental friendliness of products is important. The farming of natural and highquality vegetables is very important and acquires special relevance for good nutrition and improving the health of the entire nation.

Ecologically pure vegetables, melons and potato products may well become a national brand. The significance of this increases with the accession of Kazakhstan to the World Trade Organization.

In Kazakhstan, organic farming occupies 303.4 thousand hectares and about 300 thousand tons of organic products are grown. However, there are no potatoes, vegetables and melons among them. In the near future, it is planned to increase the volume of organic farming in vegetables up to $2.0 \%$, melon $-2.5 \%$, potato $-2.8 \%$.

Kazakhstan fully meets the domestic demand for potatoes, vegetables and melons and there is a significant overgrowing. In this regard, there is an urgent need to search for the market. The advantage of the country can be naturalness, i.e., ecologically pure and high-quality products. Kazakhstan can be at the center of attention of the global community as a producer and supplier of organic products.

Kazakhstani scientist and economist Grigoruk notes that the farming of organic products is profitable and efficient from an economic point of view (Grigoruk and Klimov, 2016).

Thus, research on organic vegetable growing is relevant and important for farmers and consumers of vegetable products. In this regard, the purpose of the research was to study an influence of biofertilizers and new types of biological products for the yield and quality of vegetables in the South-East of Kazakhstan.

\section{Materials and Methods}

\section{Fields Details}

The research was carried out at the experimental fields of the Kazakh Research Institute of Potato and Vegetable Growing (KazRIPVG) located in the foothill zone of the South-East of Kazakhstan and on the northern slope of the Zailiysky Alatau Mountains (1,000$1,050 \mathrm{~m}$ above sea level). 
The South-East Kazakhstan (Almaty region) is a large region of the country farming potatoes and vegetables.

The climate of the foothill zone of the South-East of Kazakhstan is sharply continental, characterized by large daily and annual variations in air temperature, cold winters and prolonged hot summers.

The air temperature reaches the minimum values in January $\left(-32-35^{\circ} \mathrm{C}\right)$, the average being $6-14^{\circ} \mathrm{C}$, the maximum values are in July $\left(+37-43^{\circ} \mathrm{C}\right)$, the average being $+22-25^{\circ} \mathrm{C}$. The warm period is $240-275$ days and the frost-free period is 140-170 days. The sum of positive temperatures (above $0^{\circ} \mathrm{C}$ ) is $3,450-3,750^{\circ} \mathrm{C}$ and the sum of active temperatures (above $10^{\circ} \mathrm{C}$ ) $-3,100-3,400^{\circ} \mathrm{C}$.

The relative air humidity reaches its maximum in winter (85-90\%) and minimum in summer (35-40\%). On average, in the warm period it is within $50-60 \%$.

The hydrothermal coefficient is $0.7-1.0$. The annual amount of precipitation is $350-600 \mathrm{~mm}$, during the warm period 120-200 $\mathrm{mm}$ (Recommendations, 2005).

The soil cover of the foothill zone of the South-East of Kazakhstan is represented by the most diverse types of soils (chernozem, chestnut, serozem).

The soil of the experimental fields of KazRIPVG is dark chestnut and medium loamy. The soil layer contains 2.9$3.0 \%$ humus, $0.18-0.20 \%$ of total nitrogen and $0.19-0.20 \%$ of total phosphorus. The content of $\mathrm{P}_{2} \mathrm{O}_{5}$ is $30-40 \mathrm{mg} \mathrm{kg}$ soil and $\mathrm{K}_{2} \mathrm{O}$ is $350-390 \mathrm{mg} \mathrm{kg}$. The cation exchange capacity is $20-21$ meq. per $100 \mathrm{~g}$. The reaction of the soil solution is slightly alkaline $(\mathrm{pH} 7.3-7.4)$. The volumetric mass of the soil is $1.1-1.2 \mathrm{~kg} / \mathrm{cm}^{3}$ and the lowest moisture capacity is $26.6 \%$. As a result of long-term use (more than 60 years) in irrigated vegetable farming, dark chestnut soils underwent a significant change in the basic parameters of fertility (Buribaeva and Aytbaeva, 2013).

\section{Sample Preparation and Analytical Methods}

In the field experiments and laboratory studies, classical methods were used. For example, for field experiments, taking into account the yield (with statistical processing of the obtained data) and the analysis of the quality of vegetables (dry matter - weight method (drying); total sugar - according to Bertrand; - according to Murray; nitrates - by potentiometry using ion-selective electrodes) on the basis of the research the field experiment methodology was used (Dospehov, 1985), a technique of an experimental business in vegetable growing and melon-growing (Byelik, 1992). Also, in the research with biofertilizers and biopreparations was used the methodology of agrochemical research (Yudin, 1980).

Objects of research: Vegetable crops (cabbage, cucumber, tomato), organic fertilizers (biohumus, manure, bird droppings, straw) and biopreparations (MERS, Biosok).

For comparison, mineral fertilizers were studied in the experiments. From nitric fertilizers, ammonium nitrate was used $(34.5 \%$ a.i., N), from phosphoric double superphosphate $\left(46 \%\right.$ a.i., $\left.\mathrm{P}_{2} \mathrm{O}_{5}\right)$ and from potassium - potassium chloride $\left(60 \%\right.$ a.i., $\left.\mathrm{K}_{2} \mathrm{O}\right)$.

The area of the experimental plot is $35 \mathrm{~m}^{2}(3.5 \times 10$ $\mathrm{m})$, the repetition of the experiments is 4 -fold.

The agrotechnics of vegetable crops in experiments were generally accepted for the foothill zone of the SouthEast of Kazakhstan, implemented in accordance with the recommendations of KazRIPVG (RSFWSEK, 2014).

\section{Results and Discussion}

The most available and regulated in the field conditions elements of organic vegetable farming are: Resistant and tolerant to harmful organisms, natural (non-GMO) varieties of vegetable crops; biological vegetable rotation; organic fertilizers; biological method of plant protection from pests; agritechnical method of weed control; seed dressing against diseases and pests by complex preparations instead of ground application of highly toxic pesticides; minimization of technological processes to reduce the mechanical load on the soil; progressive water saving technologies for preventing erosion of the fertile soil layer (irrigation erosion) and improving the phytosanitary condition of vegetable plantations. In the organic vegetable farming, emphasis should first be put on the local conditions and resources.

One of the main elements of organic vegetable farming is the use of local organic fertilizers instead of mineral fertilizers. The vegetable crops require high fertilizer rates due to their agribiological features. The vegetables crops, forming high yields of basic and by-products, are taking out a large number of nutrients from the soil, thereby reducing the soil reserves. The return of nutrient elements in the form of mineral fertilizers is associated with high costs for the purchase of expensive industrial fertilizers, as well as the introduction of toxic elements (heavy metals, chlorine, fluorine, nitrates) into the soil (Sirota and Nadezhkin, 2008; Tagirov and Shakirov, 2014).

Taking into account the above, KazRIPVG has been conducting research since 2015 with a view to develop "green vegetable growing" by biologizing the basic elements of agro-technology. One of the tasks of the project is the development of an alternative biological system for the fertilization of vegetable crops by using local organic fertilizers and biopreparations. This paper shows the results for 2015-2016.

In irrigated vegetable production, much attention is paid to the productivity of vegetables. Each hectare of irrigated arable land is of great value, especially in the foothill zone of the South-East of Kazakhstan, where highly fertile soils and sufficient water resources are concentrated. Therefore, all new scientific developments (selection achievements, technologies, etc.) should be aimed at increasing the productivity of vegetable crops. The yield of vegetable crops has been the main indicator of the effectiveness of agricultural technologies. Taking 
this into account, the authors in their studies on the development of elements of "green" vegetable farming, along with other important indicators, identified the productivity of vegetable crops with the use of various types of local organic fertilizers and biopreparations.

The most significant and widely used local organic fertilizers include manure, bird droppings and straw.

Manure is a complete organic fertilizer containing all the elements of nutrition necessary for plants. One ton of manure contains $5 \mathrm{~kg}$ of nitrogen, $2.5 \mathrm{~kg}$ of phosphorus, 6 $\mathrm{kg}$ of potassium, $7 \mathrm{~kg}$ of calcium, $1.5 \mathrm{~kg}$ of magnesium, 1 $\mathrm{kg}$ of sulfur, $6 \mathrm{~g}$ of boron, $60 \mathrm{~g}$ of manganese, $5 \mathrm{~g}$ of copper, $25 \mathrm{~g}$ of zinc, $0.5 \mathrm{~g}$ of molybdenum and $0.1 \mathrm{~g}$ of iodine on the average. Manure also serves as a source of carbon dioxide $\left(\mathrm{CO}_{2}\right)$. Manure consists of $70-75 \%$ of water and 25 $30 \%$ of dry matter. Of the total amount of organic matter of the manure used, about $70 \%$ are mineralized and the rest (30\%) goes to soil humus, thereby improving the soil fertility. The effective action of manure lasts 2-3 years. In the first year, plants use $20-25 \%$ of nitrogen, $30 \%$ of phosphorus and $60 \%$ of potassium contained in manure. In the second year, approximately the same amount of nitrogen and phosphorus and $20 \%$ of potassium is used.

Bird dropping is a valuable, concentrated and fast organic fertilizer, which consists of $55-60 \%$ of water and $40-45 \%$ of dry matter. One ton of chicken manure contains an average of $22 \mathrm{~kg}$ of nitrogen, $18 \mathrm{~kg}$ of phosphorus, $11 \mathrm{~kg}$ of potassium, $24 \mathrm{~kg}$ of calcium, $7 \mathrm{~kg}$ of magnesium and $4 \mathrm{~kg}$ of sulfur. From raw chicken manure in the year of application, plants use $30-40 \%$ of nitrogen, $35-45 \%$ of phosphorus and $60-80 \%$ of potassium.

Straw is an affordable organic fertilizer. One ton of straw contains $5 \mathrm{~kg}$ of nitrogen, $2.5 \mathrm{~kg}$ of phosphorus and 8 $\mathrm{kg}$ of potassium. On top of chopped straw, it is necessary to apply nitrogen fertilizers in the norm of $20-30 \mathrm{~kg} / \mathrm{ha}$ (for the rapid mineralization of straw without reducing the assimilable nitrogen in the soil). The effectiveness of 1 ton of straw equals to 3-4 tons of manure.

The results of the studies have shown that the use of organic fertilizers for vegetable crops in different combinations shows a fairly high effect.

In experiments with white cabbage under nonfertilized control, the lowest yield of cabbage was 29.05 t/ha (Table 1). Under fertilizer control, where the recommended rates of mineral fertilizers were applied $\left(\mathrm{N}_{180} \mathrm{P}_{90} \mathrm{~K}_{90}\right)$, $38.95 \mathrm{t} / \mathrm{ha}$ of standard products were obtained. In three variants of the experiment with organic fertilizers, the variant with NPK fertilizers had higher harvest: $60 \mathrm{t} / \mathrm{ha}$ manure $-40.1 \mathrm{t} / \mathrm{ha}$; biohumus - $39.65 \mathrm{t} / \mathrm{ha}$; manure, $60 \mathrm{t} / \mathrm{ha}+$ straw, $3 \mathrm{t} / \mathrm{ha}+\mathrm{N}_{30}-42.75 \mathrm{t} / \mathrm{ha}$. Here, the cabbage harvest increase to the unfertilized control was $34.08 ; 36.49$ and $47.16 \%$. In the variant with NPK, the harvest of cabbage was obtained after applying bird droppings ( $5 \mathrm{t} / \mathrm{ha}$ ) together with straw ( $3 \mathrm{t} / \mathrm{ha}$ ) and $\mathrm{N}_{30}$ (to strengthen the decomposition of straw) into the soil under cabbage - $38.8 \mathrm{t} / \mathrm{ha}$. Cabbage is very responsive to the application of organic fertilizers. This explains the significant increase in the productivity of cabbage of different species. In other variants of the experiment, the harvest of the cabbage was lower than under the fertilized control (NPK), however, at the same time, they were much higher than the pure control. Biofertilizers provided 33.45-34.6 t/ha yield. Here, in addition, 4.4$5.55 \mathrm{t} /$ ha is obtained, which is $15.15-19.10 \%$ of the control. It is very important. Therefore, without the use of chemical fertilizers, due to biofertilizers, higher levels of cabbage yield can be obtained.

In experiments with cucumber, the yield differed significantly between the control and fertilized variants. In the control without fertilizers, an average yield of $15.55 \mathrm{t} / \mathrm{ha}$ was obtained in 2 years on average. In the fertilized plot, a yield of $20.1 \mathrm{t} /$ ha were obtained where mineral fertilizers were applied to grow cucumbers in the recommended norm $\left(\mathrm{N}_{90} \mathrm{P}_{90} \mathrm{~K}_{90}\right)$. Four variants of the experiment with organic fertilizers exceeded NPKcontrol (background) in the yield. The application of 40 $\mathrm{t} / \mathrm{ha}$ of manure provided $23.25 \mathrm{t} / \mathrm{ha}$ of cucumber yield; 40 $\mathrm{t} / \mathrm{ha}$ of manure together with $3 \mathrm{t} / \mathrm{ha}$ of straw and $\mathrm{N}_{30}$ provided $39.95 \mathrm{t} / \mathrm{ha} ; 5 \mathrm{t} / \mathrm{ha}$ of bird droppings with $3 \mathrm{t} / \mathrm{ha}$ of straw and $\mathrm{N}_{30}$ provided $21.9 \mathrm{t} / \mathrm{ha} ; 4 \mathrm{t} / \mathrm{ha}$ biohumus provided $22.3 \mathrm{t} / \mathrm{ha}$. Here, the excess of the unfertilized control was $49.52,88.75,40.84$ and $47.59 \%$. At the variant level with the NPK, the yield was obtained when using the biofertilizers, such as MERS and Biosok on cucumbers (Table 2). Cucumber is very responsive to various types of organic fertilizers. This explains the significant increase in the productivity of the crop in the experiments compared to the use of organic fertilizers.

In experiments with tomato, the yields differed significantly depending on the conditions of mineral nutrition of the crop (Table 3). Without fertilizers, the yield of commercial products was the lowest in experience which is $29.1 \mathrm{t} / \mathrm{ha}$. On a mineral field $\left(\mathrm{N}_{150} \mathrm{P}_{120} \mathrm{~K}_{90}\right), 39.05 \mathrm{t} / \mathrm{ha}$ of tomato were obtained, which is a sufficiently high ripened yield. In comparison with the NPK control, a higher yield and a significant yield increase was ensured by the variant, where plants were fertilized with a combination of $30 \mathrm{t} / \mathrm{ha}$ manure, $3 \mathrm{t} / \mathrm{ha}$ straw and $\mathrm{N}_{30}$. It the variant with NPK, a yield was obtained by using $30 \mathrm{t} /$ ha of semi-peredable manure, 5 $\mathrm{t} /$ ha of bird droppings, $3 \mathrm{t} /$ ha of straw and $\mathrm{N}_{30}$ and $4 \mathrm{t} / \mathrm{ha}$ of biohumus. Biofertilizers MERS and Biosok had a positive impact on tomato productivity where $4.8 \mathrm{t} / \mathrm{ha}$ and $4.2 \mathrm{t} / \mathrm{ha}(16.49$ and $14.33 \%)$ of the yield were additionally received.

Tomato is less responsive to organic fertilizers compared to cabbage and cucumber and better uses the aftereffect of fertilizers. In addition, a number of types of organic fertilizers require considerable costs on purchase and application. In this regard, their smaller norms were taken in the tomato experiment. Therefore, the effect of organic fertilizers is less pronounced in the experiments with tomato than cabbage and cucumber. Nevertheless, tomato obtained fairly high results from organic fertilizers. 
Table 1: The effect of organic fertilizers and biopreparations on the yield of cabbage

\begin{tabular}{|c|c|c|c|c|c|}
\hline \multirow[b]{2}{*}{ Experiment variants } & \multicolumn{3}{|c|}{ Average harvest of cabbage, $\mathrm{t} / \mathrm{ha}^{1}$} & \multicolumn{2}{|c|}{ Additional yield } \\
\hline & 2015 & 2016 & Average & $\mathrm{t} / \mathrm{ha}$ & $\%^{2}$ \\
\hline Control (without fertilizers) & 29.6 & 28.50 & 29.05 & - & - \\
\hline $\mathrm{N}_{180} \mathrm{P}_{90} \mathrm{~K}_{90}$ (mineral) & 38.7 & 39.20 & 38.95 & 9.90 & 34.08 \\
\hline Manure, 60 t/ha & 40.5 & 39.70 & 40.10 & 11.05 & 38.04 \\
\hline Bird dropping, $5 \mathrm{t} / \mathrm{ha}$ & 35.4 & 33.80 & 34.60 & 5.55 & 19.10 \\
\hline Straw $3 \mathrm{t} / \mathrm{ha}+\mathrm{N}_{30}$ & 36.2 & 32.40 & 34.30 & 5.25 & 18.07 \\
\hline Manure, $60 \mathrm{t} / \mathrm{ha}+$ straw, $3 \mathrm{t} / \mathrm{ha}+\mathrm{N}_{30}$ & 43.8 & 41.70 & 42.75 & 13.70 & 47.16 \\
\hline Bird dropping, 5 t/ha + straw, 3 t/ha $+\mathrm{N}_{30}$ & 39.0 & 38.60 & 38.80 & 9.75 & 33.56 \\
\hline Biohumus, 4 t/ha & 41.4 & 37.90 & 39.65 & 10.60 & 36.49 \\
\hline MERS, 1 1/ha ${ }^{3}$ & 34.9 & 32.00 & 33.45 & 4.40 & 15.15 \\
\hline Biosok, 5 1/ha & 34.3 & 32.50 & 33.70 & 4.65 & 16.01 \\
\hline $\mathrm{SD}^{4}$ & & 2.49 & 3.51 & & \\
\hline
\end{tabular}

${ }^{1}$ Ton per hectare; ${ }^{2}$ Percentage; ${ }^{3}$ Liter per hectare; ${ }^{4}$ Standard deviation

Table 2: The effect of organic fertilizers and biopreparations on the yield of cucumber

\begin{tabular}{|c|c|c|c|c|c|}
\hline \multirow[b]{2}{*}{ Experiment variants } & \multicolumn{3}{|c|}{ Average harvest of cucumber, $\mathrm{t} / \mathrm{ha}^{1}$} & \multicolumn{2}{|c|}{ Additional yield } \\
\hline & 2015 & 2016 & Average & $\mathrm{t} / \mathrm{ha}$ & $\%^{2}$ \\
\hline Control (without fertilizers) & 16.50 & 14.60 & 15.55 & - & - \\
\hline $\mathrm{N}_{180} \mathrm{P}_{90} \mathrm{~K}_{90}$ (mineral) & 20.90 & 19.30 & 20.10 & 4.55 & 29.26 \\
\hline Manure, 40 t/ha & 25.00 & 21.50 & 23.25 & 7.70 & 49.52 \\
\hline Bird dropping, $5 \mathrm{t} / \mathrm{ha}$ & 21.60 & 18.40 & 20.00 & 4.45 & 28.62 \\
\hline Straw $3 \mathrm{t} / \mathrm{ha}+\mathrm{N}_{30}$ & 20.40 & 17.80 & 19.10 & 3.55 & 22.83 \\
\hline Manure, $40 \mathrm{t} / \mathrm{ha}+$ straw, $3 \mathrm{t} / \mathrm{ha}+\mathrm{N}_{30}$ & 31.80 & 26.90 & 29.35 & 13.80 & 88.75 \\
\hline Bird dropping, 5 t/ha + straw, $3 \mathrm{t} / \mathrm{ha}+\mathrm{N}_{30}$ & 24.10 & 19.70 & 21.90 & 6.35 & 40.84 \\
\hline Biohumus, 4 t/ha & 25.30 & 20.60 & 22.95 & 7.40 & 47.59 \\
\hline MERS, $11 / \mathrm{ha}^{3}$ & 20.70 & 16.20 & 18.45 & 2.90 & 18.65 \\
\hline Biosok, 5 1/ha & 19.50 & 17.00 & 18.25 & 2.70 & 17.36 \\
\hline $\mathrm{SD}^{4}$ & 2.72 & 1.83 & & & \\
\hline
\end{tabular}

${ }^{1}$ Ton per hectare; ${ }^{2}$ Percentage; ${ }^{3}$ Liter per hectare; ${ }^{4}$ Standard deviation

Table 3: The effect of organic fertilizers and biopreparations on the yield of tomato

\begin{tabular}{|c|c|c|c|c|c|}
\hline \multirow[b]{2}{*}{ Experiment variants } & \multicolumn{3}{|c|}{ Average harvest of tomato, $\mathrm{t} / \mathrm{ha}^{1}$} & \multicolumn{2}{|c|}{ Additional yield } \\
\hline & 2015 & 2016 & Average & t/ha & $\%^{2}$ \\
\hline Control (without fertilizers) & 30.80 & 27.40 & 29.10 & - & - \\
\hline $\mathrm{N}_{180} \mathrm{P}_{90} \mathrm{~K}_{90}$ (fertilized control-background) & 42.50 & 35.60 & 39.05 & 9.95 & 34.19 \\
\hline Manure, 30 t/ha & 41.20 & 33.50 & 37.35 & 8.25 & 28.35 \\
\hline Bird dropping, $5 \mathrm{t} / \mathrm{ha}$ & 36.30 & 31.10 & 33.70 & 4.60 & 15.81 \\
\hline Straw $3 \mathrm{t} / \mathrm{ha}+\mathrm{N}_{30}$ & 34.50 & 30.40 & 32.45 & 3.35 & 11.51 \\
\hline Manure, $30 \mathrm{t} / \mathrm{ha}+$ straw, $3 \mathrm{t} / \mathrm{ha}+\mathrm{N}_{30}$ & 44.60 & 41.00 & 42.80 & 13.70 & 47.08 \\
\hline Bird dropping, $5 \mathrm{t} / \mathrm{ha}+$ straw, $3 \mathrm{t} / \mathrm{ha}+\mathrm{N}_{30}$ & 41.60 & 34.70 & 38.15 & 9.05 & 31.10 \\
\hline Biohumus, $4 \mathrm{t} / \mathrm{ha}$ & 42.80 & 35.00 & 38.90 & 9.80 & 33.68 \\
\hline MERS, 1 1/ha ${ }^{3}$ & 37.30 & 30.50 & 33.90 & 4.80 & 16.49 \\
\hline Biosok, 5 l/ha & 35.00 & 31.60 & 33.30 & 4.20 & 14.43 \\
\hline $\mathrm{SD}^{4}$ & 2.23 & 2.74 & & & \\
\hline
\end{tabular}

${ }^{1}$ Ton per hectare; ${ }^{2}$ Percentage; ${ }^{3}$ Liter per hectare; ${ }^{4}$ Standard deviation

In vegetable farming, qualitative indicators are very important, since it is closely connected with the people's health. The vegetable crops contain various types of vitamins that make up a valuable part of a person's daily nutrition. A variety of vegetable products is required daily for a full balanced diet. Vegetables are consumed fresh or after little processing. Therefore, the harvested crops should be environmentally friendly, not to harm the human body with toxins and high-vitamin, for which vegetables are appreciated. It should also be taken into account that environmentally friendly high-quality vegetable raw materials are required for the preservatives industry.

Considering the importance of the quality of vegetables for fresh food and processing, the authors did a biochemical analyzes of the harvest of vegetable crops.

It was found that the conditions of mineral nutrition have a significant effect on the biochemical composition of vegetables. The improvement of the quality of 
vegetable crops with optimal combinations of organic fertilizers was noted. The content of dry substances, sugars and vitamins increased in many types of biofertilizers. In some variants of the experiment, there was a slight decrease in a number of qualitative indicators.

In experiments with the control cabbage, an average of $10.49 \%$ of dry matter, $5.12 \%$ of total sugar and $30.48 \mathrm{mg} \%$ of vitamin $\mathrm{C}$ were contained. In the cabbage yield with mineral fertilizers, $10.55 \%$ of the dry matter, $5.53 \%$ of total sugar and $31.21 \mathrm{mg} \%$ of vitamin $\mathrm{C}$ were contained. That is, the optimal standards of macro nutrients $\left(\mathrm{N}_{180} \mathrm{P}_{90} \mathrm{~K}_{90}\right)$ to fertilize the cabbage recommended by the KazRIPVG improves the quality of products. In the experiment variants with organic fertilizers and biopreparations, the content of dry matter was $9.44-10.73 \%$, total sugar - 4.51-5.93\%, vitamin C - 27.72-36.00 $\mathrm{mg} \%$. At the same time, better indicators were obtained in the variant with joint application of organic fertilizers and in the variant with MERS biopreparation (Table 4).

In the experiments with cucumber without chemical fertilizers (control), an average of $5.47 \%$ dry matter, $2.11 \%$ total sugar and $5.24 \mathrm{mg} \%$ vitamin $\mathrm{C}$ were contained (Table 5). In cucumber buttons, grown using balanced norms of mineral fertilizers $\left(\mathrm{N}_{90} \mathrm{P}_{90} \mathrm{~K}_{90}\right)$, the content of nutrients increased: Dry matter is $5.52 \%$, total sugar $-2.38 \%$ and vitamin $\mathrm{C}-5.83 \mathrm{mg} \%$. In the variants with bioorganic fertilizers, the content of dry matter varied within the range of $5.12-5.61 \%$, total sugar is 1.84-2.62\%, vitamin C - 6.04-7.49 $\mathrm{mg} \%$.

In the experiments with tomato in the unfertilized control variant, the yield contained $6.38 \%$ of dry matter,
$2.55 \%$ of total sugar, $19.08 \mathrm{mg} \%$ of ascorbic acid (vitamin C) (Table 6). When applying the recommended norms of nitrogen-phosphorus-potassium fertilizers $\left(\mathrm{N}_{120} \mathrm{P}_{150} \mathrm{~K}_{90}\right)$ for the culture, the qualitative indices were close to the variant without fertilizers: Dry matter - $6.55 \%$, total sugar $-2.53 \%$ and vitamin $\mathrm{C}-17.28 \mathrm{mg} \%$. When using organic fertilizers and biopreparations for tomato, the quality indicators were higher in general. Hence, the dry matter content in the yield was $6.15-6.79 \%$, total sugar - 2.58-2.88\% and vitamin C - 18.55-20.67 mg\%.

Nitrates have been studied specifically as an important environmental factor in vegetable farming. Organic fertilizers and biopreparations contributed to the yield of vegetables with low nitrate content. This is a very positive result.

The excessive and increased accumulation of nitrates in vegetables is an acute problem of vegetable farming. About $70 \%$ of the total amount of nitrates enter the human body from vegetables. Therefore, the ecological purity of nitrate products is very important. These studies have shown that the content of nitrates in vegetables varies markedly depending on the type of culture and the types of fertilizers. According to the data of biochemical analyzes, when applying various kinds and combinations of organic fertilizers and biopreparations, the content of nitrates in cabbage, cucumber and tomato yields is much lower than the maximum permissible standards (late cabbage is 500 $\mathrm{mg} \mathrm{kg}$ of raw mass, cucumber and tomato $150 \mathrm{mg} \mathrm{kg}$ ), which confirms the safety of the grown products.

Table 4: The effect of bioorganic fertilizers on the quality of cabbage head

\begin{tabular}{lllll}
\hline Experiment variants & Dry matter, $\%$ & Total sugar, $\%$ & Vitamin $\mathrm{C}, \mathrm{mg}^{\mathbf{2}}{ }^{2}$ & $\mathrm{Nitrates,} \mathrm{mg} / \mathrm{kg}^{3}$ \\
\hline Control (without fertilizers) & 10.49 & 5.12 & 30.48 & 113 \\
$\mathrm{~N}_{180} \mathrm{P}_{90} \mathrm{~K}_{90}$ (fertilized control) & 10.55 & 5.53 & 31.21 & 200 \\
Manure, $60 \mathrm{t} / \mathrm{ha}^{4}$ & 10.06 & 5.26 & 32.46 & 168 \\
Bird dropping, $5 \mathrm{t} / \mathrm{ha}$ & 9.55 & 5.39 & 28.80 & 180 \\
Straw $3 \mathrm{t} / \mathrm{ha}+\mathrm{N}_{30}$ & 10.66 & 5.55 & 30.84 & 139 \\
Manure, $60 \mathrm{t} / \mathrm{ha}+$ straw, $3 \mathrm{t} / \mathrm{ha}+\mathrm{N}_{30}$ & 10.41 & 5.28 & 27.72 & 165 \\
Bird dropping, $5 \mathrm{t} / \mathrm{ha}+$ straw, $3 \mathrm{t} / \mathrm{ha}+\mathrm{N}_{30}$ & 9.55 & 5.47 & 30.35 & 187 \\
Biohumus, $4 \mathrm{t} / \mathrm{ha}$ & 9.76 & 5.14 & 30.35 & 141 \\
MERS, $1 \mathrm{l} / \mathrm{ha}^{5}$ & 10.73 & 4.51 & 36.00 & 135 \\
Biosok, $5 \mathrm{l} / \mathrm{ha}$ & 9.44 & 5.93 & 29.10 & 134
\end{tabular}

${ }^{1}$ Percentage; ${ }^{2}$ Milligram percentage; ${ }^{3}$ Milligram/kilogram; ${ }^{4}$ Ton per hectare; ${ }^{5}$ Liter per hectare

Table 5: The effect of bioorganic fertilizers on the quality of cucumber button

\begin{tabular}{|c|c|c|c|c|}
\hline Experiment variants & Dry matter, $\%^{1}$ & Total sugar, $\%$ & Vitamin $\mathrm{C}, \mathrm{mg} \mathbf{\%}^{2}$ & Nitrates, $\mathrm{mg} / \mathrm{kg}^{3}$ \\
\hline Control (without fertilizers) & 5.47 & 2.11 & 5.24 & 88 \\
\hline $\mathrm{N}_{180} \mathrm{P}_{90} \mathrm{~K}_{90}$ (fertilized control) & 5.52 & 2.38 & 5.83 & 90 \\
\hline Manure, $40 \mathrm{t} / \mathrm{ha}^{4}$ & 5.08 & 2.29 & 6.04 & 83 \\
\hline Bird dropping, 5 t/ha & 5.48 & 2.62 & 7.15 & 77 \\
\hline Straw $3 \mathrm{t} / \mathrm{ha}+\mathrm{N}_{30}$ & 5.61 & 1.99 & 6.52 & 96 \\
\hline Manure, $40 \mathrm{t} / \mathrm{ha}+$ straw, $3 \mathrm{t} / \mathrm{ha}+\mathrm{N}_{30}$ & 5.29 & 1.84 & 7.49 & 82 \\
\hline Bird dropping, 5 t/ha + straw, 3 t/ha $+\mathrm{N}_{30}$ & 5.36 & 2.22 & 6.73 & 95 \\
\hline Biohumus, $4 \mathrm{t} / \mathrm{ha}$ & 5.15 & 2.25 & 6.39 & 96 \\
\hline MERS, $11 / \mathrm{ha}^{5}$ & 5.12 & 2.31 & 6.38 & 87 \\
\hline Biosok, 5 1/ha & 5.55 & 2.38 & 7.07 & 77 \\
\hline
\end{tabular}

${ }^{1}$ Percentage; ${ }^{2}$ Milligram percentage; ${ }^{3}$ Milligram/kilogram; ${ }^{4}$ Ton per hectare; ${ }^{5}$ Liter per hectare 
Table 6: The ffect of bioorganic fertilizers on the quality of tomato

\begin{tabular}{|c|c|c|c|c|}
\hline Experiment variants & Dry matter, $\%^{1}$ & Total sugar, $\%$ & Vitamin $\mathrm{C}, \mathrm{mg} \%^{2}$ & Nitrates, $\mathrm{mg} / \mathrm{kg}^{3}$ \\
\hline Control (without fertilizers) & 6.38 & 2.55 & 19.08 & 58 \\
\hline $\mathrm{N}_{180} \mathrm{P}_{90} \mathrm{~K}_{90}$ (fertilized control) & 6.55 & 2.53 & 17.28 & 60 \\
\hline Manure, $30 \mathrm{t} / \mathrm{ha}^{4}$ & 6.76 & 2.87 & 19.86 & 55 \\
\hline Bird dropping, 5 t/ha & 6.71 & 2.88 & 18.60 & 81 \\
\hline Straw $3 \mathrm{t} / \mathrm{ha}+\mathrm{N}_{30}$ & 6.36 & 2.73 & 19.14 & 90 \\
\hline Manure, $30 \mathrm{t} / \mathrm{ha}+$ straw, $3 \mathrm{t} / \mathrm{ha}+\mathrm{N}_{30}$ & 6.72 & 2.73 & 20.07 & 115 \\
\hline Bird dropping, 5 t/ha + straw, 3 t/ha $+\mathrm{N}_{30}$ & 6.79 & 2.82 & 19.93 & 130 \\
\hline Biohumus, 4 t/ha & 6.60 & 2.82 & 18.55 & 114 \\
\hline MERS, 1 1/ha ${ }^{5}$ & 6.15 & 2.83 & 20.67 & 97 \\
\hline Biosok, 5 1/ha & 6.61 & 2.58 & 18.55 & 105 \\
\hline
\end{tabular}

${ }^{1}$ Percentage; ${ }^{2}$ Milligram percentage; ${ }^{3}$ Milligram/kilogram; ${ }^{4}$ Ton per hectare; ${ }^{5}$ Liter per hectare

\section{Conclusion}

In Kazakhstan, the production of ecologically safety products are at an early stage of development. The organic products are imported mainly from Europe, which entails high prices. Hence, there are all opportunities for the development and production of the national organic farming.

According to the research results of KazRIPVG, the application of bioorganic fertilizers for vegetable crops shows a rather high effect. It has been established that all types of organic fertilizers and biopreparations provide an increase in the yield of vegetables in comparison with the unfertilized controls. The yield of cabbage increased by $15.2-47.2 \%$, cucumber by $17.4-88.7 \%$, tomato by $14.4-47.1 \%$. It is noted that some types of organic fertilizers are superior in efficiency to mineral fertilizers.

Bioorganic fertilizers had a positive effect on the quality of vegetables, cabbage, cucumber and tomato yields increased the content of dry substances, sugars and vitamins. The content of nitrates in the products was significantly lower (1.5-3 times on the average) than the maximum permissible standards.

Based on these experimental data, it is possible to make the conclusion on high efficiency of local organic fertilizers and new Kazakhstani biopreparations, available to national vegetable farmers and the opportunities of their use in vegetable farming instead of chemical mineral fertilizers for the cultivation of ecologically pure organic vegetables. It was also developed of an alternative biological system for the fertilization of vegetable crops by using local organic fertilizers and biopreparations.

\section{Acknowledgment}

The results of this scientific research were obtained within the framework of the grant project on "Development of "green" vegetable production by biologizing the main elements of agrotechnology", in the implementation of which, along with the authors of this paper, other scientific staff of Department for technology of cultivation and seed production of vegetable crops of KazRIPVG took part, namely Toilybayeva Nagima Nazarovna and Buribayeva Laura Abdiraevna, PhDs;
Seidazimova Dinara Askarkyzy, PhD; Aytbayeva Bakhyt Utarovna, Balgabayeva Raikhan Kerimbaevna, masters. The authors express their great appreciation and gratitude to their colleagues for active participation and significant contribution to field experiments, laboratory research and obtaining the experimental data.

\section{Author's Contributions}

All authors equally contributed in this work.

\section{Ethics}

This article is original and contains unpublished material. The corresponding author confirms that all of the other authors have read and approved the manuscript and there are no ethical issues involved.

\section{References}

Borisov, V.A., 2008. Complex use of agrochemicals as a basis for an ecologically safe system of fertilizing vegetable crops. Vegetable-Growing, 15: 66-68.

Boyhan, G.E., W.T. Kelley, D.B. Langston, A.N. Sparks and S. Culpepper et al., 2009. Commercial organic vegetable production. Univ. Georgia.

Bruulsema, T., 2003. Productivity of organic and conventional cropping systems. Organic Agric. Sustainabil. Markets Policies.

Buribaeva, L.A. and B.U. Aitbaeva, 2013. Stabilization and improvement of soil fertility through application of organic and mineral fertilizers in vegetable rotations in the South-East of Kazakhstan: Scientific provision of potato and vegetable growing. Achievements Prospects.

Byelik, B.F., 1992. Methods of Experimental Work in the Vegeculture and Melon. 1st Edn., Agropromizdat, Moscow.

Dospehov, B.I., 1985. Methods of Field Experience. 1st Edn., Agropromizdat, Moscow.

Dubovitsky, A.A. and E.A. Klimentova, 2014. Problems and prospects of vegetable growing. Technol. Food Proc. Industry AIC - Healthy Food Prod., 3: 89-95. 
Ferreira, V.B., T.T.C. Da Silva, S.R.M. Couto and A.U.O.S. Srur, 2015. Total phenolic compounds and antioxidant activity of organic vegetables consumed in Brazil. Food Nutrit. Sci., 6: 798-798.

Ganush, G., 2013. Perspectives of development of production of ecologically safe (organic) food products in Belarus. Sustainable development of agriculture in Belarus under new conditions. Res. Agroindustrial Complex Nat. Acad. Sci. Belarus.

Gosling, P. And M. Shepherd, 2005. Long-term changes in soil fertility in organic arable farming systems in England, with particular reference to phosphorus and potassium. Agric., Ecosyst. Environ., 105: 425-432.

Grigoruk, V.V. and E.V. Klimov, 2016. The development of organic agriculture in the world and Kazakhstan. Ankara.

Kharitonov, S.A., 2011. Organic agriculture as an innovative direction in Agrarian development. Agrarian Russia, 2: 54-56.

Khodakovskaya, O.V., 2011. World tendencies of development of organic farming. Economy Work Manage. Agric., 4: 70-73.

Kirchmann, H., L. Bergstro, T. Katterer, L. Mattsson and S. Gesslein, 2007. Comparison of long-term organic and conventional crop-livestock systems on a previously nutrient-depleted soil in Sweden. Agron. J., 99: 960-972.

Lotter, D.W., 2003. Organic agriculture. J. Sustainable Agric., 21: 59-128.

Malkov, S.V., V.V. Markelov, B.I. Barabanschikov, A.M. Potemkina and G.Y. Polozov et al., 2006. Reduction of the crop plant allergenicity due to soil treatment with bacillus oligonitrophilus KU-1 Strain. // Rivista di Biologia / Biol. Forum, 99: 161-165.

OSDASRK, 2017. Official statistical data of the agency for statistics of the Republic of Kazakhstan. Date Views.

OFG, 2017. Organic farming in Germany. www.bmel.de/EN/Agriculture/SustainableLandUse/ Texte/OrganicFarmingInGermany.html.

Paull, J. and B. Hennig, 2016. Atlas of organics: Four maps of the world of organic agriculture. J. Organ., 3: $25-32$.

Paull, J. and K. Lyons, 2008. Nanotechnology: the next challenge for organics. J. Organic Syst., 3: 3-22.
Pomigalov, A.S., 2004. Organic agriculture on our planet. Achievements Sci. Technol. Agro-Industrial Complex, 1: 17-19.

RSFWSEK, 2014. Recommendations for Spring Field Works in the South-East of Kazakhstan. 1st Edn., Aleurone, Almaty.

Recommendations, 2005. Agricultural Management System in Almaty Oblast. 1st Edn., Nurly Alem, Almaty, pp: 296.

Sharmanov, T.S. and M.M. Aidzhanov, 2000. Minimum norms of consumption of basic food products for different age groups of the population of the Republic of Kazakhstan. Health Disease, 1: 1-3.

Sirota, S.M. and S.M. Nadezhkin, 2008. Ecological aspects of the long-term use of fertilizers in the vegetable crop rotation. Actual Direct. Dev. Sci. Res. Potato Vegetable Growing.

Stolze, M., M. Hartmann and H. Moschitz, 2012. Report on total costs of three organic certification systems in six European countries with particular focus on organic supply chains.

Tagirov, M.S. and R.S. Shakirov, 2014. Adaptive technologies for the production of environmentally friendly products and reproduction of soil fertility. Bull. Russian Acad. Agric. Sci., 2: 19-21.

Willer, H. and J. Lernoud, 2015. The World of Organic Agriculture: Statistics and Emerging Trends 2015. 1st Edn., Research Institute of Organic Agriculture (FiBL) and Bonn, Date Views.

Willer, H. and J. Lernoud, 2016a. The World of Organic Agriculture: Statistics and Emerging Trends 2016. 1st Edn., FiBL-IFOAM Report, Frick and Bonn.

Willer, H. and J. Lernoud, 2016b. The World of Organic Agriculture: Statistics and Emerging Trends 2016. 1st Edn., The Research Institute of Organic Agriculture (FiBL) and Organics International (IFOAM).

Willer, H., J. Lernoud and L. Kilcher, 2013. The World of Organic Agriculture: Statistics and Emerging Trends 2013. 1st Edn., FiBL-IFOAM Report, FrickandBonn.

Yudin, F.A., 1980. Method of Agrochemical Research. 1st Edn., Agropromizdat, Moscow. 